Logos Universality Mentality Education Novelty, Section:

Economical and Administrative Sciences

ISSN: 2284-5984 (print), ISSN: 2284 - 5984 (electronic)

Covered in: CEEOL, Index Copernicus, Ideas RePeC, EconPapers, Socionet

\title{
THE BIOMASS - A SOLUTION FOR THE REPUBLIC OF MOLDOVA ENERGY EQUATION?
}

\author{
Oxana SOIMU \\ Victoria TROFIMOV
}

Doi: http://dx.doi.org/10.18662/lumeneas.2015.0201.02

Logos Universality Mentality Education Novelty, Section: Economical and Administrative Sciences, 2015, Volume II, Issue 1, pp: $13-24$

\author{
Published by: \\ Lumen Publishing House \\ On behalf of:
}

Lumen Research Center in Social and Humanistic Sciences 


\title{
The Biomass - a Solution for the Republic of Moldova Energy Equation?
}

\author{
Oxana SOIMU ${ }^{1}$ \\ Victoria TROFIMOV ${ }^{2}$
}

\begin{abstract}
More than a decade Moldova's energy sector requires restructuring in strategic terms from existing energy resources, almost total dependence on imports to consumption and infrastructure. Likewise, in the recent years, it is more and more appreciable the use of biomass as energy source in Moldova whose outcomes could have a twofold impact (positive and negative). Thus, in this paper authors will present at a glance Moldovan energy sector and will shed light on new trends of energy production from biomass by highlighting the opportunities and exbibiting the threats it implies. In addition, authors will make a foray into the successful experiences of some European and non-European countries and in an innovative manner they will try adapting these experiences to the realities of the Republic of Moldova. Finally, the main expectation of the research is to formulate a new Energy Vision for the next decade.
\end{abstract}

Keywords: Biomass; Republic of Moldova Energy Strategy.

\footnotetext{
${ }^{1}$ PhD, Spain, oxana.soimu@gmail.com.

$2 \mathrm{PhD}$, Trade Cooperative University of Moldova, Republic of Moldova, victoria.trofimov11@gmail.com.
}

Soimu, O., Trofimov, V. (2015). The Biomass - a Solution for the Republic of Moldova Energy Equation?. Logos Universality Mentality Education Novelty, Section: Economical and Administrative Sciences, II (1), 13-24. Doi: http://dx.doi.org/10.18662/lumeneas.2015.0201.02 


\section{Introduction}

The Energy drama in Republic of Moldova (henceforth Moldova) keeps affecting for decades all economic and social levels. The rising energy necessity and massive energy imports appeal nowadays for renewable energy sources and especially from biomass. On the other hand, the development of alternative and renewable sources of energy of Moldova usually is an effect raised from positive and negative externalities that is created by economic and political environment in the country and global energy trends.

In this article, authors question whether the biomass is the solution for Moldovan energy equation. Here, it should be noted that giving answers to this question is not an easy issue just because holistic quantitative and qualitative justifications concentrated into operational and strategic trajectories are needed. For this reason, authors propose a research divided into two phases: quantitative and qualitative, but both under experimental methodology.

In quantitative terms, in order to reach measurable results and comparable conclusions and adaptable to the Moldovan economic, social and environmental realities, a Granger Causality is considered to be relevant. For instance, to be analyzed the causal relationship between renewable energy consumption (biomass and biofuel), fossil fuel consumption (oil) and CO2 emissions in the Moldovan transport, industrial or agricultural sector using monthly data (Granger, 1969). Therefore, by observing potential unidirectional or bidirectional causal links between the four variables we can reach conclusions concerning the efficiency of using the biomass as well as conclusions of environmental order like CO2 abatement.

In qualitative terms, in order to answer to the question related to the efficiency of biomass in Moldova, authors propose employing an algorithm divided into six steps:

- First step, is to identify reference documents and suitable approach to biomass in Moldova;

- Second stage, is to identify main biomass related achievements in energy sector in Moldova;

- Third stage is to identify the existing strategic support that exists in Moldova; 
- Fourth stage, is to analyze the recent trends in energy sector of Moldova (imports, consumption, production);

- Fifth stage, is to design a basic methodological scheme in order to reach the key points that future Moldova Bioenergy Action Plan 2030 should contain;

- Sixth, is to define a 2030 vision for the biomass for energy in Moldova.

\section{Literature review}

So far, there is a large body of literature tackling the biomass efficiency. "In the face of Europe's growing dependency on fossil fuels, biomass is one of the key ways to increase security of energy supply and energy sustainability of Europe." (COM (2005) 628 final). Therefore European Union "encouraging the use of biomass as an alternative source of energy" in December of 2005 establish the Biomass Action Plan with the four sustainability criteria for biomass (Ibid.).

Besides, considering the studies portrayed in the "Biomass Futures" (funded by the European Union's Intelligent Energy Program), authors consider that at this stage of development of biomass in Moldova, the suitable approach is resource focused (manure, energy crop and crop residues) and the straw potential ${ }^{3}$ (Studies and calculations performed by experts within "Moldova Energy and Biomass Project' (UNDP Moldova, 2011-2014) ${ }^{4}$.

Defining the biomass as solution for addressing the energy security threats in Moldova is not an easy process. For this reason it is considered important to cite the Moldova Energy and Biomass Project ${ }^{5}$ designed to small cities and rural spaces ${ }^{6}$, The Republic of Moldova Energy Strategy $2030^{7}$ and data provided by National Bureau of Statistics of Moldova.

\footnotetext{
3 Biomass Futures. "Review and assessment of existing biomass potentials". Retrieved August 20, 2015 from http://www.biomassfutures.eu/webtools/webtool_intro.php

${ }^{4}$ Financed by European Union and implemented and co-financed by UNDP Moldova (Henceforth UNDP Moldova). Retrieved August 3, 2015 from http://biomasa.md/newsletter-ro/

${ }^{5}$ Ibid.

${ }^{6} \mathrm{http}: / /$ www.biomasa.md/startpage-en/

${ }^{7}$ Government of Republic of Moldova. Decision no. 102 of 05.02.2013 regarding The Republic of Moldova Energy Strategy 2030. Published: 08.02.2013 in the Official
} 


\section{Modelling a Bioenergy Strategy for Moldova}

Undertaking first analysis of information provided by the three sources mentioned above, authors observe that at the first sight, for Moldova at present, the biomass is indeed a solution when considering the heating in rural areas and also has a positive environmental impact because of intensive use of residuals.

The Moldova Energy and Biomass Project (UNDP Moldova) for the period 2011-2014 with extension until 2017 in Moldova is an open window and a first step to addressing the energy sector issues, but Moldova needs a Bioenergy Action Plan aligned to the EU energy requirements. Taking into consideration traditional aspects and closeness to the EU culture as best model for Moldova could serve the

\section{"Romania Bioenergy/Biomass Action Plan for the Centre Region 2014-2020"}

So far, in strategic as well as operational terms Moldova has a good platform for training, communication, enhancement of bioenergy private sector development and public institutions involvement through Moldova Energy and Biomass Project 2011-2014 (UNDP Moldova). Therefore, among achievements are: new work places were created (350.000), CO2 emissions reduced by 30.000 tonnes, new businesses launched (35), specialized training (1.227 persons), intensive promotion and communication through video spots (12), brochures (50.000), project awards (48) and a unique platform of communication (www.biomasa.md), (UNDP Moldova).

From agricultural and forestry waste, Moldova produces fuel only for heating boilers although it can be produced fuel for transport and thermoelectrical local or regional stations. For Moldova it is critical to cover not only heating sector but also the transport and industrial sector.

On the other hand, Moldova has concretely defined the future energy sector objectives, priorities and expectations within the "Republic of Moldova Energy Strategy by 2030" (Government of

Journal Nr. 27-30, art Nr: 146. Retrieved September 6, 2015 from http://lex.justice.md/md/346670/

${ }^{8}$ Supported by Intelligent Energy Europe. 
Moldova, 2013). In the same source there are also identified barriers that stagnates the development of the energy sector and namely:

- high price, cost and tariffs;

- low industrial capacity;

- high household consumption;

- industrial stagnation;

- massive import of energy sources;

- obsolete infrastructure that generates massive energy losses;

- lack of consciousness concerning rational energy use and environmental impact;

- low energy market liberalization;

- low competitiveness;

- low financing from private sector;

Box 1. The Republic of Moldova Energy Strategy 2030 relevant aspects for the present study

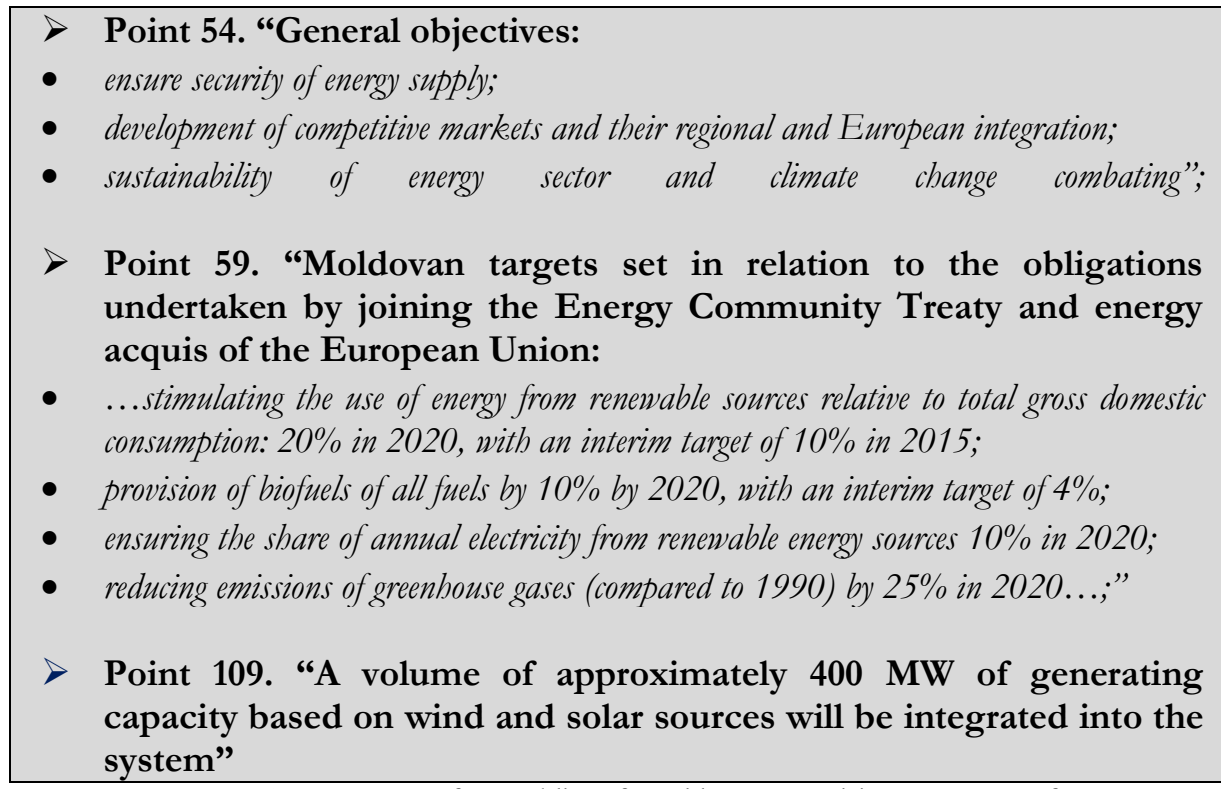

Source: Government of Republic of Moldova . Decision no. 102 of 05.02.2013 regarding The Republic of Moldova Energy Strategy 2030. Published: 08.02.2013 in the Official Journal Nr. 27-30, art Nr: 146. Retrieved September 6, 2015 from http://lex.justice.md/md/346670/

Moldova keeps being almost totally dependent on the coal import (Fig.1) and only a small quantity of electricity and petroleum 
products are produced (according to Republic of Moldova National Bureau of Statistics Data), predominantly in winter. The imported gas is almost totally consumed (Ibid.).

Right now the challenge is whether the existing infrastructure and raw material for biomass production is enough to cover a percentage of fossil fuels consumption from imports.

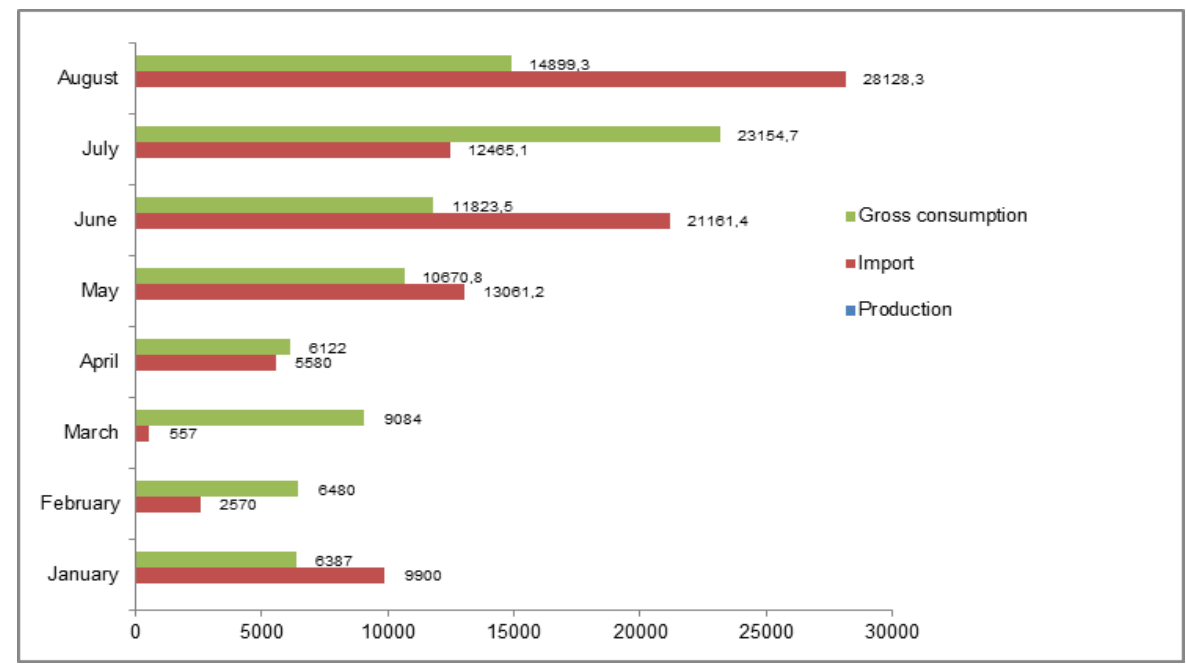

Source: Made by authors from data from National Bureau of Statistics of Moldova

Fig. 1 - Stocks, inputs and coal consumption, January-August, 2015 (Tonnes)

For this overall state of things authors decide to build a simplified diagram of bioenergy in Moldova from production to the destinations and transformation into other products. In the following scheme (Fig. 2) concerning the biomass production for fuel for the transport sector and pellets for heating and thermoelectrical stations there are actually portrayed the steps that Moldova made until nowadays and the next steps to be done. The future expectations just emphasize the need for Bioenergy Action Plan.

Soimu, O., Trofimov, V. (2015). The Biomass - a Solution for the Republic of Moldova Energy Equation?. Logos Universality Mentality Education Novelty, Section: Economical and Administrative Sciences, II (1), 13-24. Doi: http://dx.doi.org/10.18662/lumeneas.2015.0201.02 
The Biomass - a Solution for the Republic of Moldova Energy Equation? Oxana SOIMU, Victoria TROFIMOV

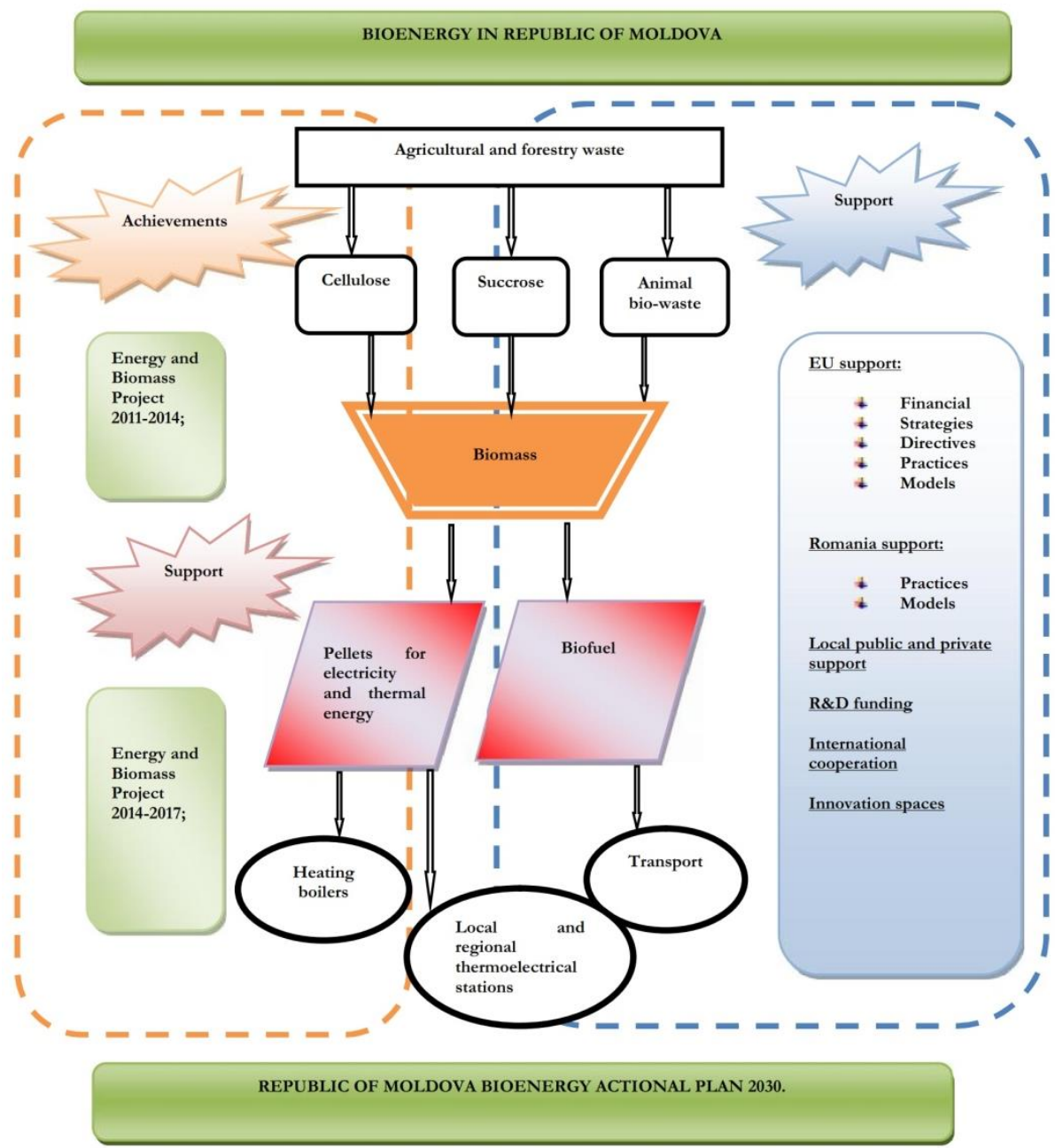

Source: Performed by authors 9

Fig. 2 - Bioenergy Action Plan 2030 scheme (present and future)

In order to elaborate an Action Plan for Moldova bioenergy sector authors propose to follow the following algorithm:

${ }^{9}$ For the "Moldova Energy and Biomass Project" for the periods 2011-2014 and 20142017 sources: UNDP Moldova and www.biomasa.md

Soimu, O., Trofimov, V. (2015). The Biomass - a Solution for the Republic of Moldova Energy Equation?. Logos Universality Mentality Education Novelty, Section: Economical and Administrative Sciences, II (1), 13-24. Doi: http://dx.doi.org/10.18662/lumeneas.2015.0201.02 
1. Identify the main aspects, variables and elements related to energy sector;

- Consumption culture;

- Institutional framework;

- Legal framework;

- National interests;

- International cooperation;

- Economic drivers and potential;

- Threats to energy security;

- Areas of interventions;

- Specialisation and diversification;

- Energy supply and demand;

- Suppliers diversifications;

- Complementarities within private-public;

- Agriculture sector supply;

- $\mathrm{R} \& \mathrm{D}$ for energy sector;

- Technologies and innovations in the energy sector;

- Competitiveness;

- Technical norms. reference:

2. What best practices, models, platforms and points of

- As the best practices suitable are experiences and practices described in the Report "European Best Practice Report Comparative assessment of national bioenergy strategies and biomass action plans in 12 EU countries" (B.A.P. Driver, 2009) ${ }^{10}$. According to the Report the 12 countries: Austria, Belgium, Finland, France, Germany, Greece, Netherlands, Poland, Romania, Slovenia, Sweden and the United Kingdom are the best practices and experiences of Europe.

- Taking into consideration the close economic model and tradition, as suitable model for Moldova it is considered the Romania National Renewable Energy Action Plan (NREAP) and the Bioenergy/Biomass Action Plan for the Centre Region 2014-2020;

${ }^{10}$ Deliverable of the European project BAP DRIVER, funded under the Intelligent energy for Europe (IEE) programme Contract Nº EIE/07/118/SI2.467614 
- For the platforms: Moldova Energy and Biomass Project 2011-2017 platform (www.biomasa.md), and in terms of innovation - the European Network of Living Labs (http://www.openlivinglabs.eu/) where partners and projects can be found;

- As reference and alignment to the EU are EU directives, strategies and documents (Table 1):

Table 1. Short list of EU directives, strategies and documents in energy.

\begin{tabular}{|c|c|}
\hline $\begin{array}{c}\text { EU strategies, } \\
\text { directives and documents }\end{array}$ & $\begin{array}{l}\text { Some key points adaptable to } \\
\text { Moldova realities in the future }\end{array}$ \\
\hline $\begin{array}{l}\text { Communication from the } \\
\text { commission on Clean Power for } \\
\text { Transport: A European alternative } \\
\text { fuels strategy, Brussels, 24.1.2013 } \\
\text { COM (2013) } 17 \text { final } \\
\end{array}$ & $\begin{array}{l}\text { "to cover all modes of transport" } \\
\text { "build-up of alternative transport fuel } \\
\text { infrastructure" }\end{array}$ \\
\hline $\begin{array}{l}\text { Communication from the } \\
\text { Commission on the practical } \\
\text { implementation of the EU } \\
\text { biofuels and bioliquids } \\
\text { sustainability scheme and on } \\
\text { counting rules for biofuels } \\
\text { 2010/C } 160 / 02 \\
\end{array}$ & $\begin{array}{l}\text { Biofuels into practice and sustainability } \\
\text { criteria. }\end{array}$ \\
\hline $\begin{array}{l}\text { Energy } 2020 \text { - A strategy for } \\
\text { sustainable, competitive and } \\
\text { sustainable energy [COM (2010) } \\
\text { 639] }\end{array}$ & $\begin{array}{l}\text { "Achieving an energy efficient Europe" } \\
\text { "Ensuring the free movement of energy." } \\
\text { "Providing secure, safe and affordable } \\
\text { energy for the public and businesses" } \\
\text { "Extending Europe's lead in energy } \\
\text { technology and innovation" } \\
\text { "Securing strong international } \\
\text { partnerships" }\end{array}$ \\
\hline $\begin{array}{l}\text { Report from the Commission on } \\
\text { indirect land-use change related to } \\
\text { biofuels and bioliquids 22-12- } \\
2010 \text { COM (2010) } 811 \text { final } \\
\end{array}$ & $\begin{array}{l}\text { "consequences for the GHG emissions" } \\
\text { "indirect land-use change for biofuels" }\end{array}$ \\
\hline $\begin{array}{l}\text { Renewable Energy Directive } \\
(2009 / 28 / \mathrm{EC})\end{array}$ & $\begin{array}{l}\text { "sustainability criteria for biofuels and } \\
\text { bioliquids" }\end{array}$ \\
\hline $\begin{array}{l}\text { Green Paper - "A European } \\
\text { strategy for sustainable, } \\
\text { competitive and secure energy" } \\
{[\text { COM(2006) } 105 \text { final] }}\end{array}$ & $\begin{array}{l}\text { "Energy for growth and jobs in Europe" } \\
\text { "competitiveness and security of energy } \\
\text { supply" } \\
\text { "energy technology plan" } \\
\text { "coherent external energy policy" }\end{array}$ \\
\hline
\end{tabular}

Soimu, O., Trofimov, V. (2015). The Biomass - a Solution for the Republic of Moldova Energy Equation?. Logos Universality Mentality Education Novelty, Section: Economical and Administrative Sciences, II (1), 13-24. Doi: http://dx.doi.org/10.18662/lumeneas.2015.0201.02 


\begin{tabular}{|c|c|}
\hline $\begin{array}{l}\text { Biomass Action Plan [COM } \\
\text { (2005) } 628 \text { final] }\end{array}$ & $\begin{array}{l}\text { Biomass for heating, } \\
\text { Electricity from biomass } \\
\text { The use of biofuels in transport Boosting } \\
\text { supply of biomass }\end{array}$ \\
\hline $\begin{array}{l}\text { Energy Roadmap } 2050 \\
(\mathrm{COM}(2011) 885 \text { final of } 15 \\
\text { December } 2011)\end{array}$ & $\begin{array}{l}\text { "decarbonisation" } \\
\text { "ensuring at the same time, security of } \\
\text { supply and competitiveness" }\end{array}$ \\
\hline
\end{tabular}

What incentives for the bioenergy for Moldova:

- Prioritization in bioenergy business;

- Grants and financial support;

- Technical support;

- Sensitization, training and capacitating;

- Clusters and scientific and technology parks;

- Projections by 2020, 2030 and 2050 for transport and electricity, agricultural supply and overall energy consumption;

- Land use -biomass production-food security nexus diagnostics and projections;

- CO2 abatement;

- What innovation policies;

- Social innovation;

- Financial Plan;

- International Cooperation;

\section{Conclusion}

As it was mentioned in the abstract, by this work authors aimed to answer to the main question whether the biomass is a solution for the energy equation of Moldova. The answer is YES but in the present realities it is not covering all sectors like transport, industry and electricity production. For this reason authors propose a basic scheme to be followed in order to elaborate a Bioenergy Action Plan for Moldova 2030. The Vision for this strategic and ambitious Plan is that the biomass production in Moldova will be an energy alternative for all public and private entities ensuring at the same time food security, sustainability, cooperation and convergence with the EU policies.

Soimu, O., Trofimov, V. (2015). The Biomass - a Solution for the Republic of Moldova Energy Equation?. Logos Universality Mentality Education Novelty, Section: Economical and Administrative Sciences, II (1), 13-24. Doi: http://dx.doi.org/10.18662/lumeneas.2015.0201.02 
The Biomass - a Solution for the Republic of Moldova Energy Equation? Oxana SOIMU, Victoria TROFIMOV

\section{REFERENCES}

Biomass Futures. "Review and assessment of existing biomass potentials". Retrieved August 20, 2015 from

http://www.biomassfutures.eu/webtools/webtool intro.php

Centre Region Development Agency (2014). Bioenergy/Biomass Action Plan for the Centre Region 2014-2020. Retrieved October 30, 2015, from http://www.promobio.eu/en/document.cfm?doc $=$ show\&doc $\mathrm{id}=18$ $\underline{3}$

Communication from the Commission on Clean Power for Transport: A European alternative fuels strategy, COM (2013) 17 final. Brussels

Communication from the Commission to the Council, the European Parliament, the European Economic and Social Committee and the Committee of the Regions. Energy Roadmap 2050 (COM(2011) 885 final. Brussels

Communication from the Commission on the practical implementation of the EU biofuels and bioliquids sustainability scheme and on counting rules for biofuels 2010/C 160/02. (OJ L 160, 19.6.2010)

Communication from the Commission to the European Parliament, the Council, the European Economic and Social Committee and the Committee of the Region. Energy 2020 - A strategy for sustainable, competitive and sustainable energy [COM (2010) 639 final], Brussels

Communication from the Commission (2005). Biomass Action Plan. [COM (2005) 628 final], Brussels

Driver, B. A. P. (2009). European Best Practice Report - Comparative assessment of national bioenergy strategies and biomass action plans in $12 \mathrm{EU}$ countries-Best Practice Guidelines. Extended version. Retrieved November 10, 2015 from https://ec.europa.eu/energy/intelligent/projects/sites/ieeprojects/files/projects/documents/bap driver european best practi ce report.pdf

European Network of Living Labs (http://www.openlivinglabs.eu/)

Green Paper - "A European strategy for sustainable, competitive and secure energy" [COM (2006) 105 final]

Government of Republic of Moldova. Decision no. 102 of 05.02.2013 regarding The Republic of Moldova Energy Strategy 2030. Published: 08.02.2013 in the Official Journal Nr. 27-30, art Nr: 146. Retrieved September 6, 2015 from http://lex.justice.md/md/346670/

Granger, C. W. (1969). Investigating causal relations by econometric models and cross-spectral methods. Econometrica: Journal of the Econometric Society, 424-438.

National Bureau of Statistics of Moldova. www.statistica.md

Renewable Energy Directive (2009/28/EC)

Soimu, O., Trofimov, V. (2015). The Biomass - a Solution for the Republic of Moldova Energy Equation?. Logos Universality Mentality Education Novelty, Section: Economical and Administrative Sciences, II (1), 13-24. Doi: http://dx.doi.org/10.18662/lumeneas.2015.0201.02 
Report from the Commission on indirect land-use change related to biofuels and bioliquids 22-12-2010 COM (2010) 811 final

Romania National Renewable Energy Action Plan (NREAP). Retrieved October 30, 2015, from http://www.ebbeu.org/legis/ActionPlanDirective2009_28/national_renewable_energy _action_plan_romania_en.pdf

UNDP Moldova. Moldova. Energy and Biomass Project in Moldova. Financed by European Union and implemented and co-financed by UNDP Moldova. Retrieved Agust 3, 2015 from http://biomasa.md

UNDP Moldova. "Moldova Energy and Biomass Project. A four year path (2011 - 2014)". Retrieved November 10, 2015 from http://www.md.undp.org/content/dam/moldova/docs/Publications /MEBP\%20final\%20report_EN.pdf

\section{Biodata}

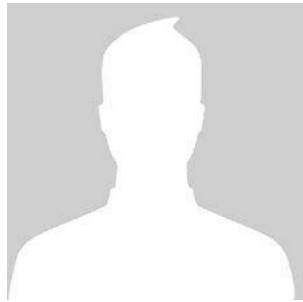

\section{PhD Oxana SOIMU}

Oxana SOIMU holds the title of $\mathrm{PhD}$ in International and Intercultural Studies. Her main interests are European Studies (regional policies and cooperation) and Security Studies. Currently she is developing her research on energy policies for developing countries focusing on the possibilities and efficiency of biomass as energy source.

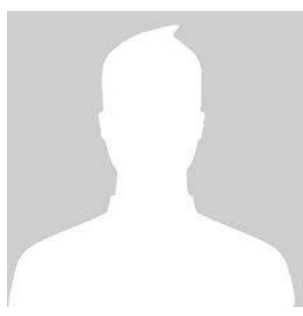

\section{PhD Victoria TROFIMOV}

Victoria TROFIMOV holds the title of $\mathrm{PhD}$ in Economics. She has a wide experience in university management and coordinated projects under the TEMPUS and ERASMUS MUNDUS Programmes. Victoria is expert in National Bureau of Statistics of Moldova, National Council of Accreditation and Attestation. Her research interests are employability and training and sustainable development. She is author / co-author of over 100 scientific and methodical publications.

Soimu, O., Trofimov, V. (2015). The Biomass - a Solution for the Republic of Moldova Energy Equation?. Logos Universality Mentality Education Novelty, Section: Economical and Administrative Sciences, II (1), 13-24. Doi: http://dx.doi.org/10.18662/lumeneas.2015.0201.02 